\title{
Comparison of trace heavy-metal levels from monitoring in the German Bight and the southwestern Baltic Sea
}

\author{
D. Schmidt \\ Deutsches Hydrographisches Institut; Wüstland 2, D-2000 Hamburg 55, \\ Federal Republic of Germany
}

\begin{abstract}
Since 1973, monitoring for selected trace heavy metals has been performed in the German Bight (North Sea) and the western Baltic Sea. This paper deals with a set of filtered and unfiltered samples from a network of 22 stations covering the whole German Bight based on a cruise with RV "Gauss" in May 1974, and a similar series of samples taken at different depths at 18 stations in the Baltic Sea in October 1974. The metals $\mathrm{Cd}, \mathrm{Cu}, \mathrm{Fe}, \mathrm{Mn}$, and $\mathrm{Ni}$ were determined by flameless atomic absorption spectrometry. Data comparison is facilitated since sampling and analytical methods were identical. Distributions of metal-content data have been calculated from unfiltered and filtered samples. Qualitative and semi-quantitative aspects of the major differences or similarities between the histograms obtained from both sea areas are discussed.
\end{abstract}

\section{INTRODUCTION}

Trace heavy metals are regarded as one of the main problem groups of substances when considering environmental pollution. Monitoring their levels is therefore necessary to learn about possible increases of their concentrations in coastal and offshore water bodies due to anthropogenic activities. "Monitoring" is defined here as the recording of trace-metal concentrations, repeated at regular intervals and continued over longer periods of time with comparable analytical techniques. It is now generally accepted that trends of environmental changes can only be determined if long time series are available. Recently, with regard to the convention on the protection of the marine environment of the Baltic Sea area ("Helsinki-Convention"), a similar definition has been adopted (Anonymous, 1978): "Monitoring means the repeated measurement of selected parameters and pollutant concentrations in order to follow changes over a period of time." In the same context the following explanation has been annexed which is also of interest here: "It is implicitly understood that the observations will form part of a warning system to determine unnatural, possibly harmful, changes in the environment. In order to register man-induced changes, the natural changes of different elements of the ecosystem must be known. Therefore, monitoring will often include registration of more or less 'natural' conditions. In its more restricted sense, the term is applied to the regular measurement of pollutant levels in relation to some standard, or in order to judge the effectiveness of a system of regulation and control. Monitoring does not encompass experimental laboratory studies." 
Reference is also made here to the many decades of careful meteorological observations on a global scale that may now supply the data essential for discovering climatological changes.

The "Deutsches Hydrographisches Institut" has, by federal legislation, the task of monitoring noxious compounds in the sea. In this framework, investigations were started by the author in 1971 to monitor trace heavy metals in sea water off the coasts of the Federal Republic of Germany, particularly in the German Bight of the North Sea, and in the southwestern Baltic Sea. From the beginning, we have placed equal emphasis on both sea areas. The number of institutions investigating both North Sea and Baltic for trace metals with equal effort, and with comparable methods for sampling and analysis, is probably rather small.

\section{ANALYSIS OF DATA AND METHODS}

Trace-metal data are available, many of them still unpublished, from RV "Gauss" cruises to the inner German Bight in 1973 and to the western Baltic Sea in 1973, to the whole German Bight and the southwestern Baltic both in 1974, and to some coastal stations of the German Bight in 1975. Some data have already been analyzed from a cruise covering the whole German Bight in 1976, from participation in the international cooperative experiment BOSEX ' 77 in the Baltic proper and from some coastal stations in the Baltic, both in 1977, and from work aboard the research platform "Nordsee" (FPN) in 1978. Samples have been preserved, where analysis is under way or has not yet been started, from a similar cruise with RV "Gauss" to the Baltic in 1976, and from a leg traversing the whole North Sea in 1977, from a RV "Meteor" cruise to the German Bight in January 1978, from work aboard FPN in 1979, and from a cruise with RV "Meteor" to the northern North Atlantic Ocean in 1979.

For this paper, a set of samples was selected from a network of 22 stations covering the whole German Bight, taken on a cruise with RV "Gauss" in May 1974 (Fig. 1). They were compared with a similar series of samples from 18 stations in the Baltic Sea, taken on a cruise with RV "Gauss" in October 1974 (Fig. 2). In the latter case, data from Stations 1 to 3 have been omitted from the calculations, since these were very coastal ones. Station 4 was first observed in the usual manner and was repeated three times during one day on the return leg of the vessel, in order to examine possible natural fluctuation. These data have been entered into the present calculations. On all stations, samplers have been set at about 3 to 6 different leviels, according to water depth.

For the purposes of this intercomparison, the concentration data for the metals cadmium, copper, iron, manganese and nickel have been selected. Sampling and analytical methods were identical for both sets of samples.

Water samples were collected at up to 6 depths, using 1.7-1 Nansen-type bottles made from polycarbonate plastic (Hydrobios, Kiel) on a PVC-coated hydrographic wire. Unfiltered samples were conserved immediately. Filtration of water from the same sampler was performed by vacuum suction in a glass apparatus through $0.4-\mu \mathrm{m}$ "Nuclepore" membrane filters. Both types of samples were filled in acid-precleaned $500-\mathrm{ml}$ bottles specially made from silica ("quartz") glass. They were rapidly deep-frozen at $-60^{\circ} \mathrm{C}$ using a special apparatus (Kryotherma, Trier). Samples were stored in commercial freezers at $-28{ }^{\circ} \mathrm{C}$ until analysis in the land-based laboratory. The samples from the 


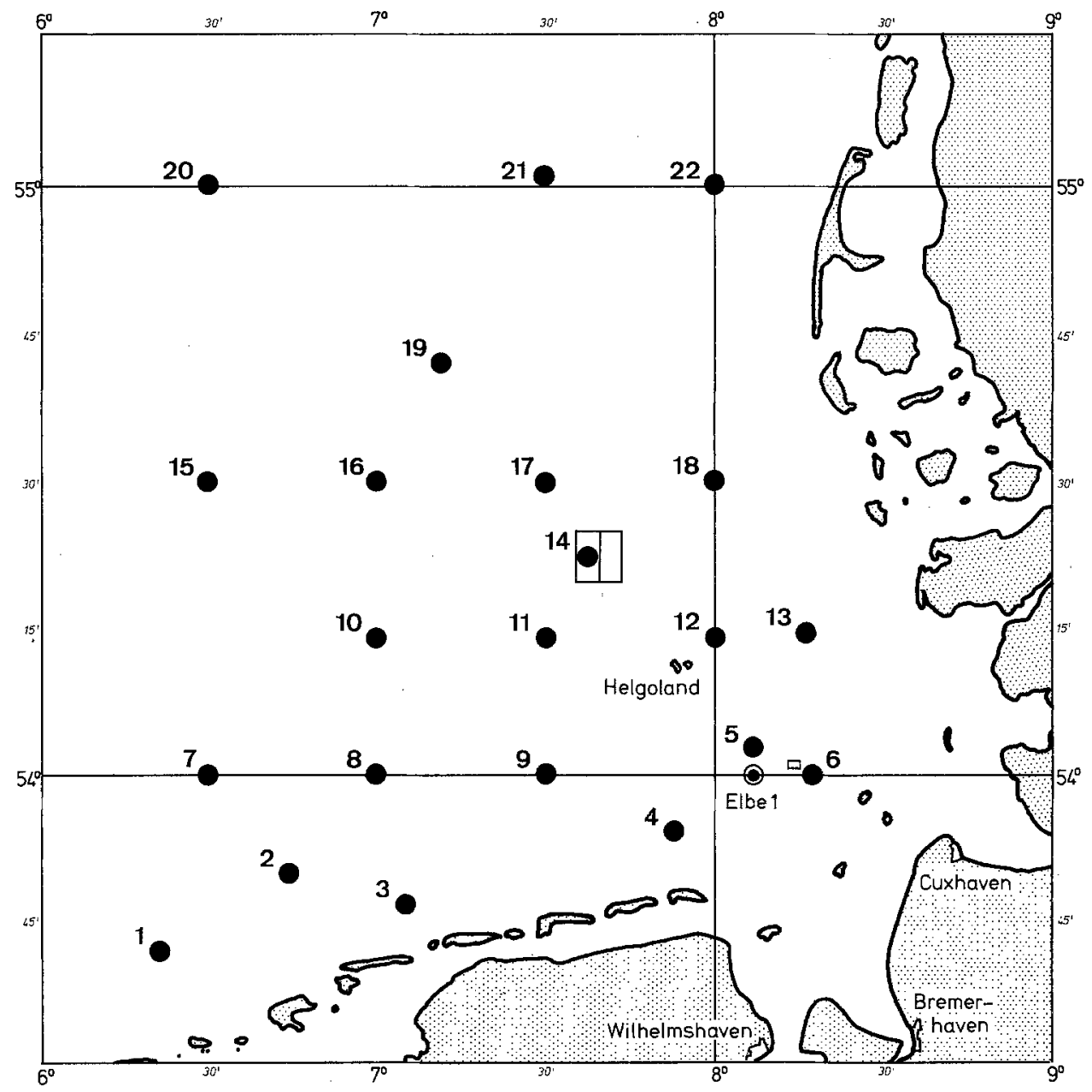

Fig. 1. Station network for RV "Gauss" cruise to the German Bight in May 1974. The rectangle around Station 14 indicates the dumping area for $\mathrm{TiO}_{2}$ waste solutions; the rectangle east of it identifies an additional area for dumping under severe westerly gale conditions. The small rectangle northwest of Station 6 shows the dumping area for digested sewage sludge from the city of Hamburg

German Bight were analyzed from November 1975 to March 1976, those from the Baltic between August 1978 and March 1979.

After thawing, acidification ( $\mathrm{HCl}$ ), chelation (APDC) and liquid/liquid-extraction (MIBK), the metals $\mathrm{Cd}, \mathrm{Cu}, \mathrm{Fe}, \mathrm{Mn}$, and $\mathrm{Ni}$ were determined by flameless atomic absorption spectrometry (AAS) using Bodenseewerk Perkin-Elmer spectrometers models 300 and 432. The standard addition method was applied for calibration. Additional details of the sampling and analysis procedure have been omitted here; they have been presented in our contribution to the Baltic Intercalibration Workshop in Kiel (Schmidt \& Neubauer, 1977) and more recently (Schmidt \& Zehle, 1979). 


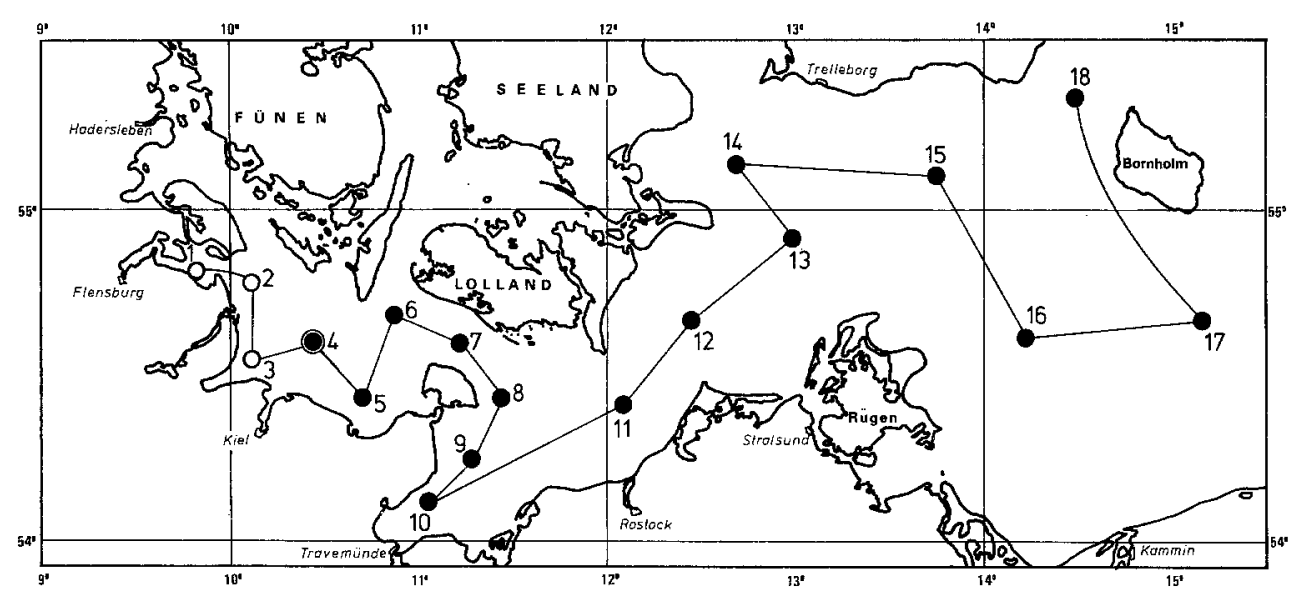

Fig. 2. Station network for RV "Gauss" cruise to the southwestern Baltic Sea in October 1974 (for explanation see text)

The analytical method has successfully been intercalibrated, in particular during the Baltic Intercalibration Workshop in Kiel (1977), and by participation in the first, third, and fourth round of intercalibrations (Jones, 1976, 1977; Bewers et al., 1978, 1979) conducted under the auspices of the former ICES Subgroup on Contaminant Levels in Sea Water that was chaired by the author.

\section{RESULTS AND DISCUSSION}

From preceding investigations (Schmidt, 1976a, b, c), particularly in the inner German Bight and the southwestern Baltic, both in 1973, and again in the greater German Bight and a larger part of the Baltic in 1974, the most obvious and remarkable observation was that large variations in metal content could be found over the sea area investigated and at different depths for certain metals. Those metals were, with decreasing degree of variations: $\mathrm{Fe}, \mathrm{Mn}, \mathrm{Ni}$. The variations could be traced back to well-known sources, like dumping, and input by major estuaries and rivers. Other metals, like $\mathrm{Cd}$, $\mathrm{Cu}, \mathrm{Zn}$, appeared to be more evenly distributed. As one example of this oceanographic variability, the levels of "particulate" and "dissolved" Fe from the cruise to the German Bight in 1974 are presented in Figure 3. From the same sampling bottle, an unfiltered sample was taken, whereas another aliquot was filtered by means of $0.4-\mu \mathrm{m}$ Nuclepore filters. Using this widely accepted filtration procedure, an artificial distribution is provided between a "dissolved" compartment and another compartment for "dissolved" plus "particulate" metals. As can be seen from Figure 3, the most prominent iron levels occur in the unfiltered samples, mainly derived from particulate iron. Very high concentrations of particulate iron are introduced through the estuaries of the Rivers Elbe and Weser. Passing along the stations to the west (Stations 6, 5, 4, 3, 2, 1), against the residual current, and then heading up north into the open German Bight, levels for particulate Fe decrease rapidly. Much of the outflow of the Elbe river water is turning up northwards (Stations 5, 12, 13,18), with relatively high values for iron in unfiltered samples. Another 
maximum is visible in the dumping area for waste solutions from titanium dioxide production northwest of Helgoland (Station 14). Similar observations were made by Weichart $(1975 \mathrm{a}, \mathrm{b})$ with a very different analytical technique. The highest concentration from the cruise was found in the lowest sampling bottle of Station 17 northwest of the dumping area $\left(702 \mu \mathrm{g} \mathrm{l^{-1 }} \mathrm{Fe}\right)$.

For at least some of the metals these features were very interesting. This led to further considerations in regard to dumping regulations and marine pollution by rivers. Hence, it did not appear reasonable to mask the oceanographic variations by calculation of mean values, e.g. for the German Bight as a whole or for the southwestern Baltic.

In the present work, a different approach was taken. All data were pooled, and only few parameters considered: metal, filtered versus unfiltered sample, German Bight

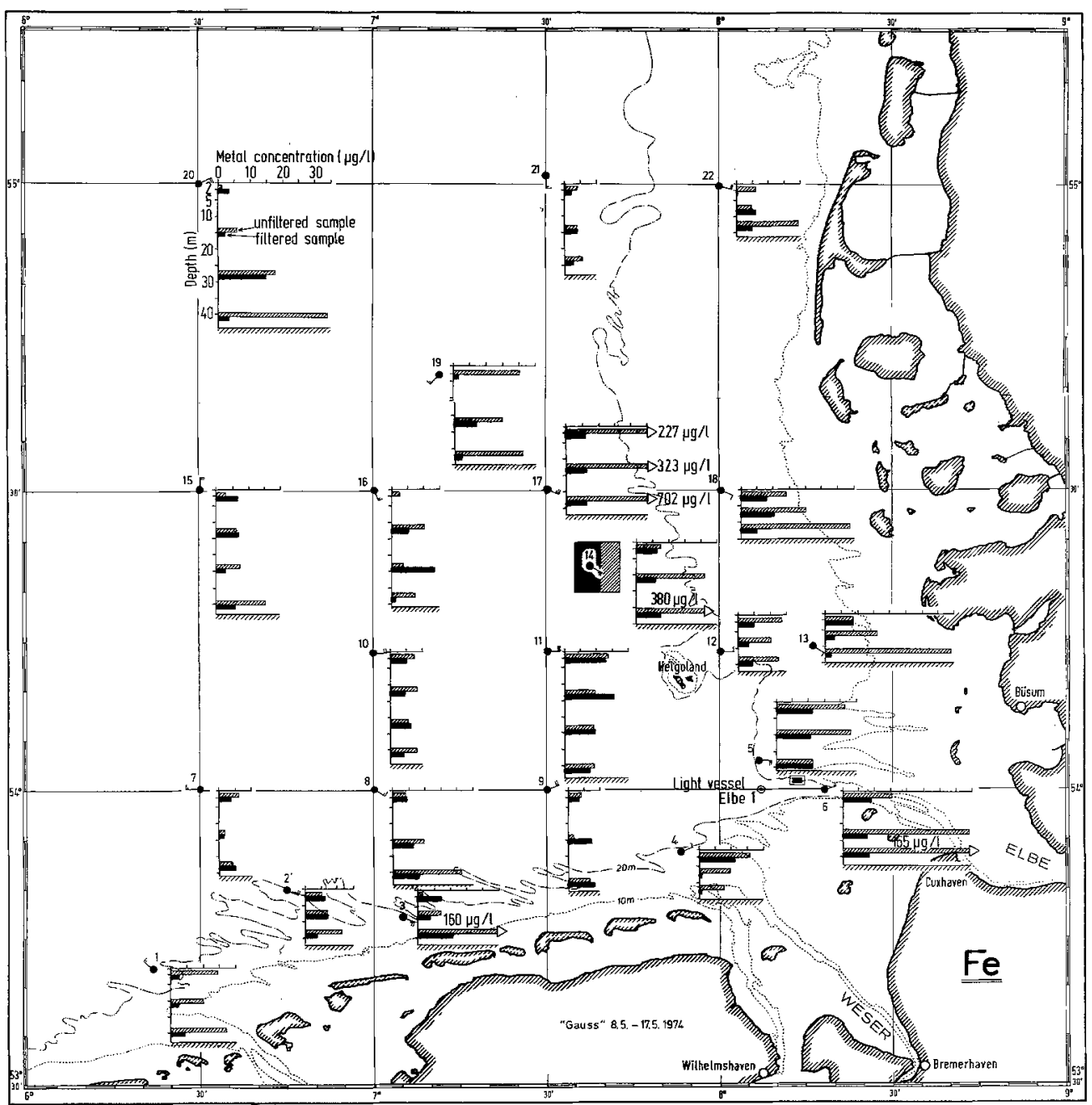

Fig. 3. Distribution of iron levels in unfiltered and filtered seawater samples. RV "Gauss" cruise to the German Bight in May 1974. Legends for small insert diagrams are given at Station 20 
versus southwestern Baltic. Consequently, while possible fine structures according to geographical area or station depth become hidden, general trends tend to reveal themselves.

The data, together with necessary information, were stored in a Hewlett Packard 9825 A desk computer. By using special programs developed within our research group, histograms have been calculated. All metal concentration values were distributed into 20 equally-spaced channels, the width of which was selected according to the range of the majority of values. The number of analytical data found in each of the channels appears on the y-axis. The total numbers of metal data used for each of the individual histograms are comparable and are indicated in the diagrams (N). For the present considerations, only the relative proportions and the general distribution patterns are of interest.

\section{Cadmium}

This metal shows a very regular distribution pattern (Fig. 4) with no significant differences between filtered and unfiltered water samples. This finding confirms results from our earlier investigations (e. g. Schmidt, 1976c); Cd tends to act like a "dissolved" metal - weakly chelated and with a low percentage bound to particulate matter. However, significant differences are apparent between histograms for the German Bight and those for the Baltic Sea. Since Cd is used as a model element in many studies on distributions of noxious heavy metals between sea water, sediment, and marine biota, and in investigations of the effects of heavy metals on the ecosystem, attention may be drawn to the relatively low concentrations found in the present work. The Cd data

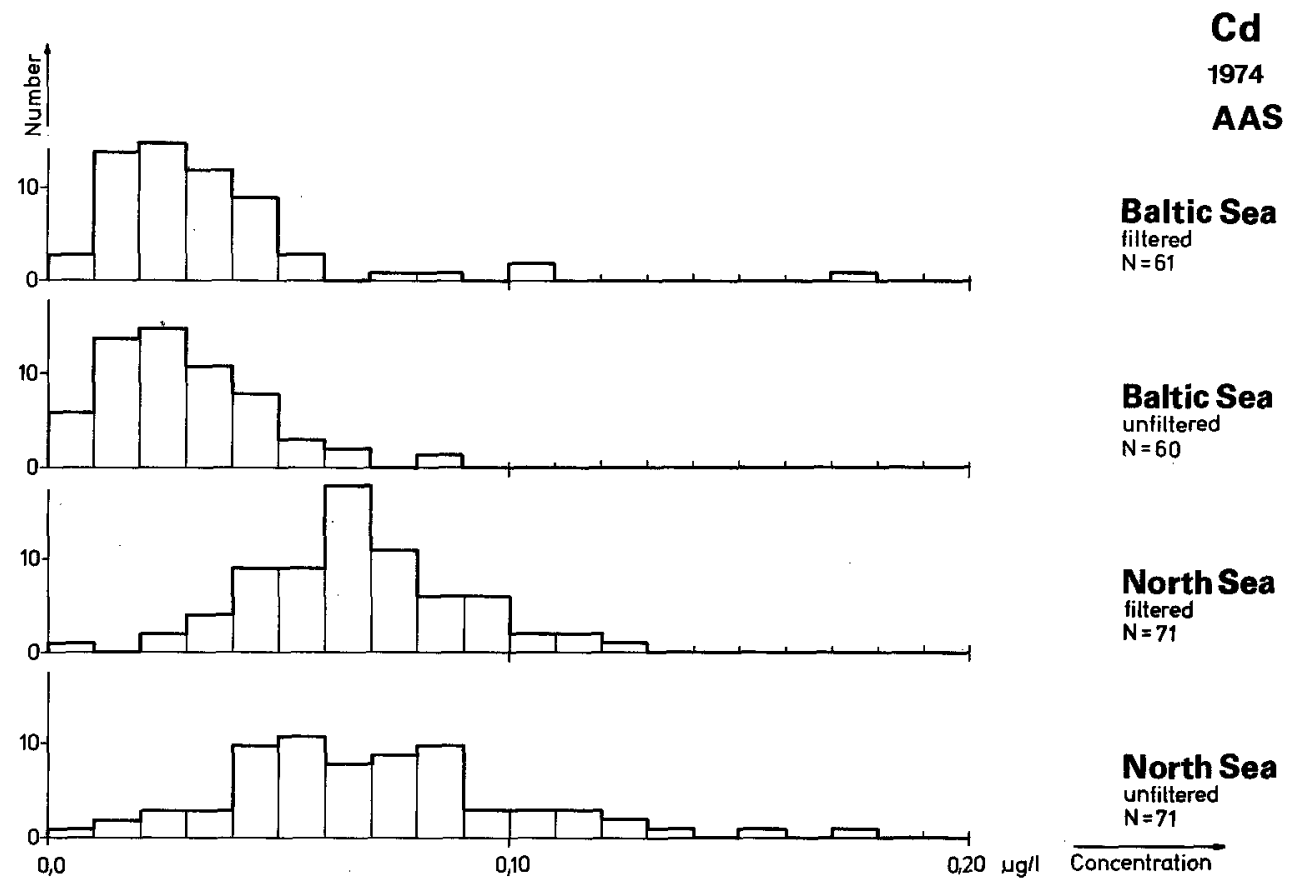

Fig. 4. Histograms for cadmium content 
cluster around a value of about $60 \mathrm{ng} \mathrm{l}^{-1}$ for the German Bight of the North Sea and around about $20 \mathrm{ng} \mathrm{l}^{-1}$ for the Baltic Sea.

Geographically, $\mathrm{Cd}$ is also very evenly distributed. For the German Bight, no particular "hot spots" can be seen. The lowest values occur at Station 20; slightly enhanced concentrations can be recognized west and east of Helgoland. For the southwestern Baltic cruise, Cd levels do not show any marked gradients or structure, neither in the different subdivisions of the area concerned nor according to depth or between filtered and unfiltered samples.

\section{Copper}

A similar distribution, compared with the case for $\mathrm{Cd}$, is displayed for $\mathrm{Cu}$ in the German Bight samples (Fig. 5). However, the distribution is very different for the samples from the Baltic. Here the levels appear to be more shifted to higher values, with a smaller degree of clustering around a mean concentration. Some of the higher concentration values in the filtered samples may be an indication of contamination by the filtering process in some cases; at that time some problems were encountered with filtration on board. In the meantime, totally new filtering equipment has been designed and put into service that will now avoid contamination sources.

The spatial distribution of $\mathrm{Cu}$ in the German Bight shows a tendency for slightly increased concentrations at some coastal stations $(2,3,4,5$ and 18$)$ that are influenced by river outflows; the lowest concentrations occur at the outermost stations $(15,16$ and 10$)$.

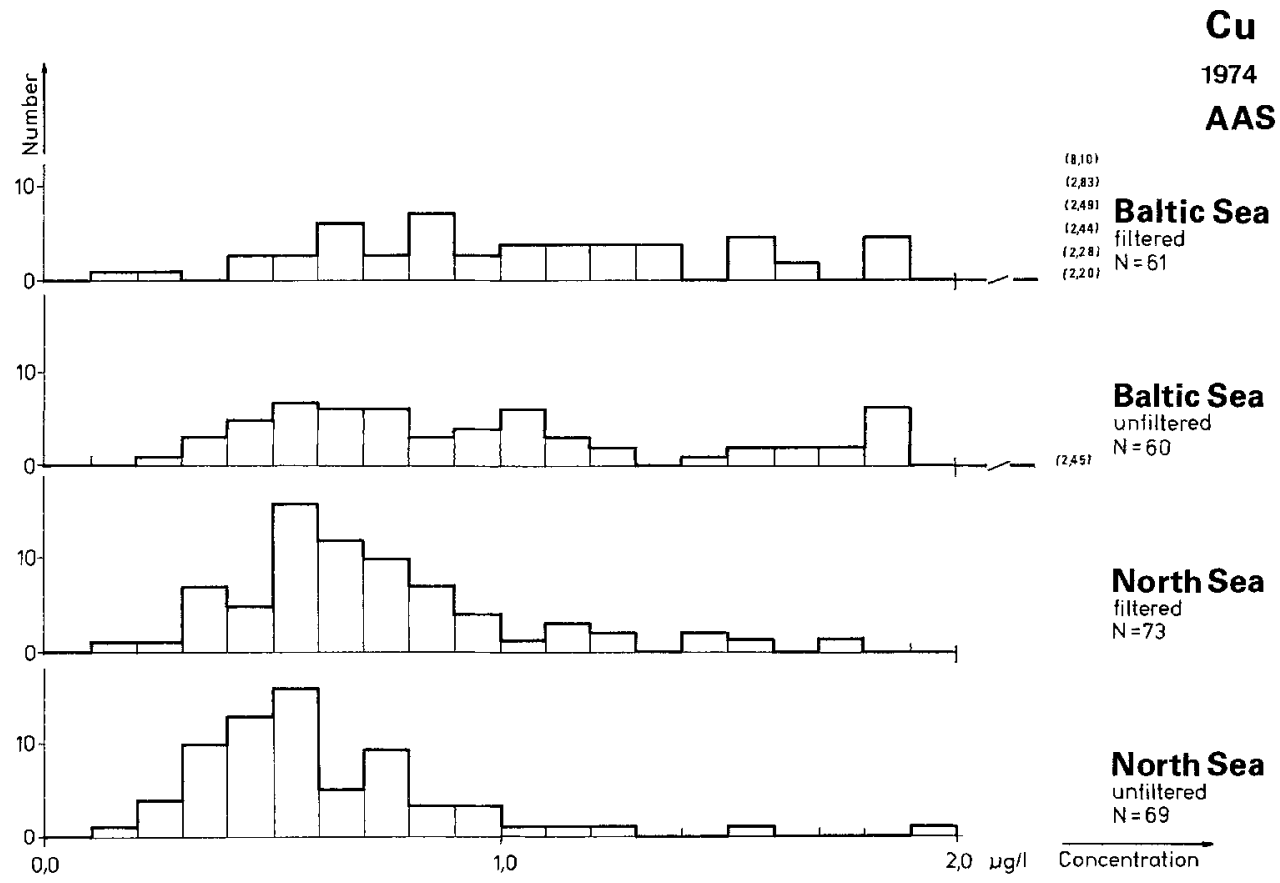

Fig. 5. Histograms for copper content 
In the case of the Baltic, slightly elevated $\mathrm{Cu}$ levels are found at Stations 9 and 10 in the Lübeck Bay and, surprisingly, at the open Baltic Stations 17 and 18, south and northwest of Bornholm Island, respectively.

\section{Iron}

Very high iron levels occur in some unfiltered samples from the North Sea (Fig. 6). They are caused by the dumping operations and the influx from the Elbe and Weser river estuaries, as discussed earlier and as shown by Figure 3. The Fe levels are greatly reduced by filtration to low concentration values with a more regular distribution pattern. This again appears as typical and has been found in our earlier investigations (e.g.) Schmidt, 1976c). In the case of the Baltic unfiltered samples, the levels are significantly shifted to the lower side, with almost no high concentrations. The few elevated Fe levels occur mainly in the lowermost samplers immediately above the bottom; increased concentrations in the upper sampling bottles are found at Station 12 of the Baltic network. The sea area investigated there does not experience any dumping of Fe wastes, nor is it influenced to a larger degree by major rivers. The levels cluster even more in one peak by filtration, falling almost exclusively into the lowermost concentration range.

The Fe data appear particularly influenced by external conditions during the cruises. According to Schmidt (1976b), meteorological parameters - like wind force and direction, wave heights, and shallowness of the sea area - are closely correlated with Fe

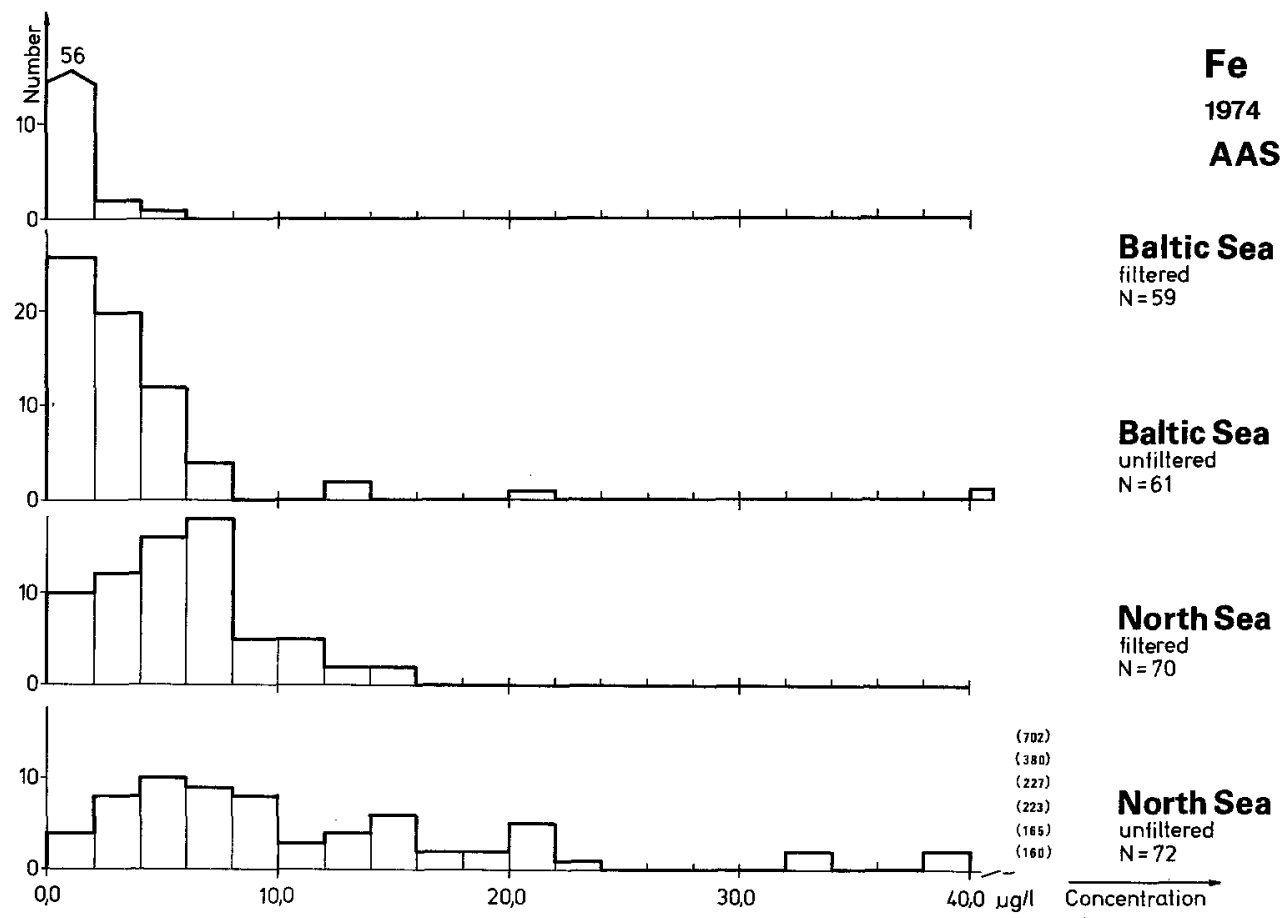

Fig. 6. Histograms for iron content 
levels in the samples containing the particulate matter, obviously caused by higher turbulence in the water and a greater sediment load.

\section{Manganese}

In principle, Mn distributions (Fig. 7) bear some resemblance to Fe patterns. This again confirms previous results (Schmidt, 1976c) claiming as typical for the German Bight that the three-dimensional distribution for Mn compared with Fe was similar, but less pronounced in variability. Very high $\mathrm{Mn}$ concentrations in unfiltered water are found at the stations surrounding the Elbe and Weser estuaries (Station 6, 5, 9, 13) and northwest of the $\mathrm{TiO}_{2}$ dumping area (Station 17). In Figure 7, however - in contrast to $\mathrm{Fe}$ - higher Mn levels are found in the Baltic Sea than in the German Bight. The highest Mn values occur here at Stations 6, 7, 8, 9, 12 and 15. In all these cases maxima are found in the lowest sampling bottle. The geochemistry of $\mathrm{Mn}$ in the Baltic Sea has been shown to be very interesting, with remarkably high concentrations of dissolved $\mathrm{Mn}$ in certain water layers (Kremling \& Petersen, 1978).

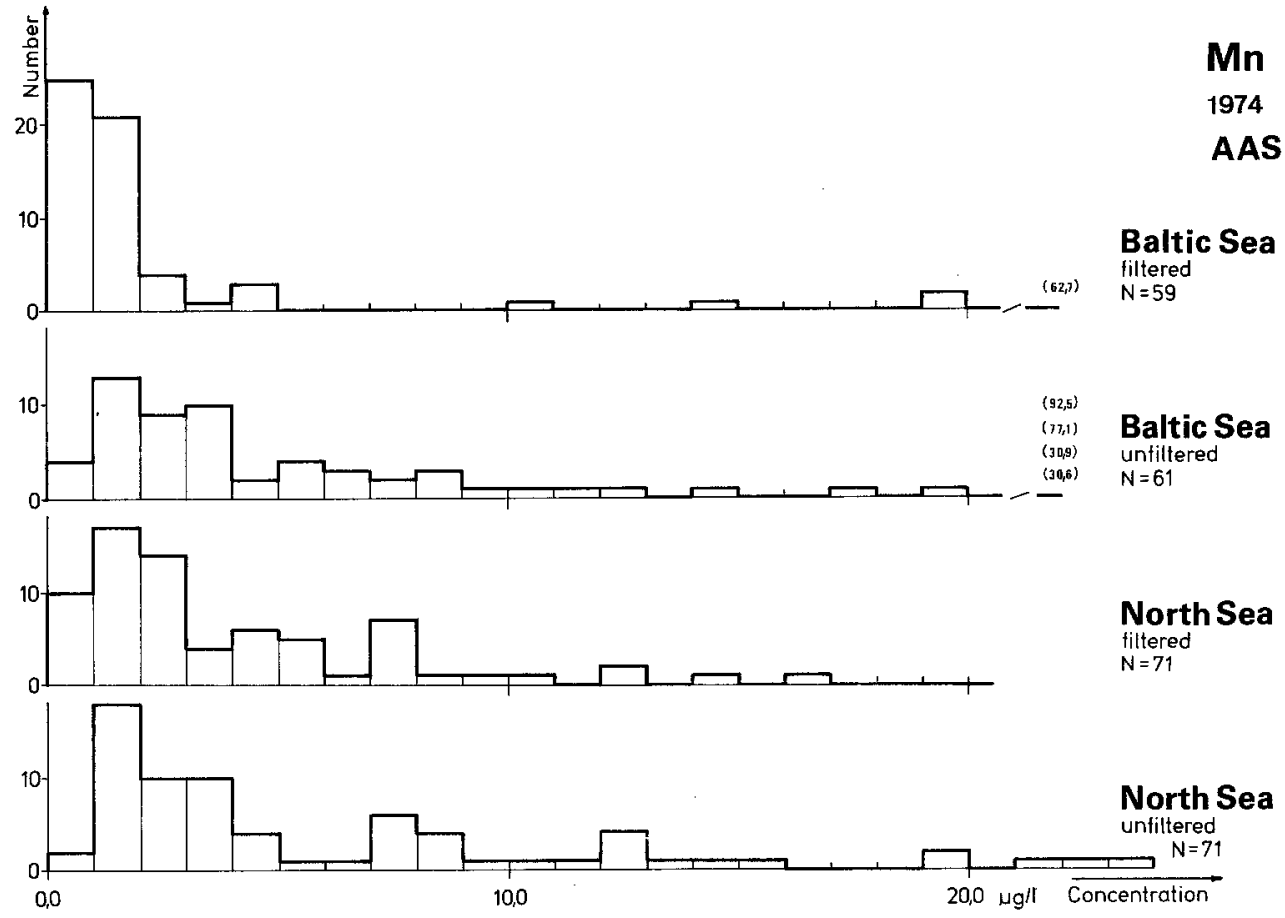

Fig. 7. Histograms for manganese content

\section{Nickel}

Although Ni exhibits chemical behavior similar to that of Fe, very different distribution patterns are evident (Fig. 8). No significant differences can be seen between filtered and unfiltered water samples both for the North Sea and Baltic Sea. The concentration values tend to cluster in the middle part of the range for the German Bight samples; in 


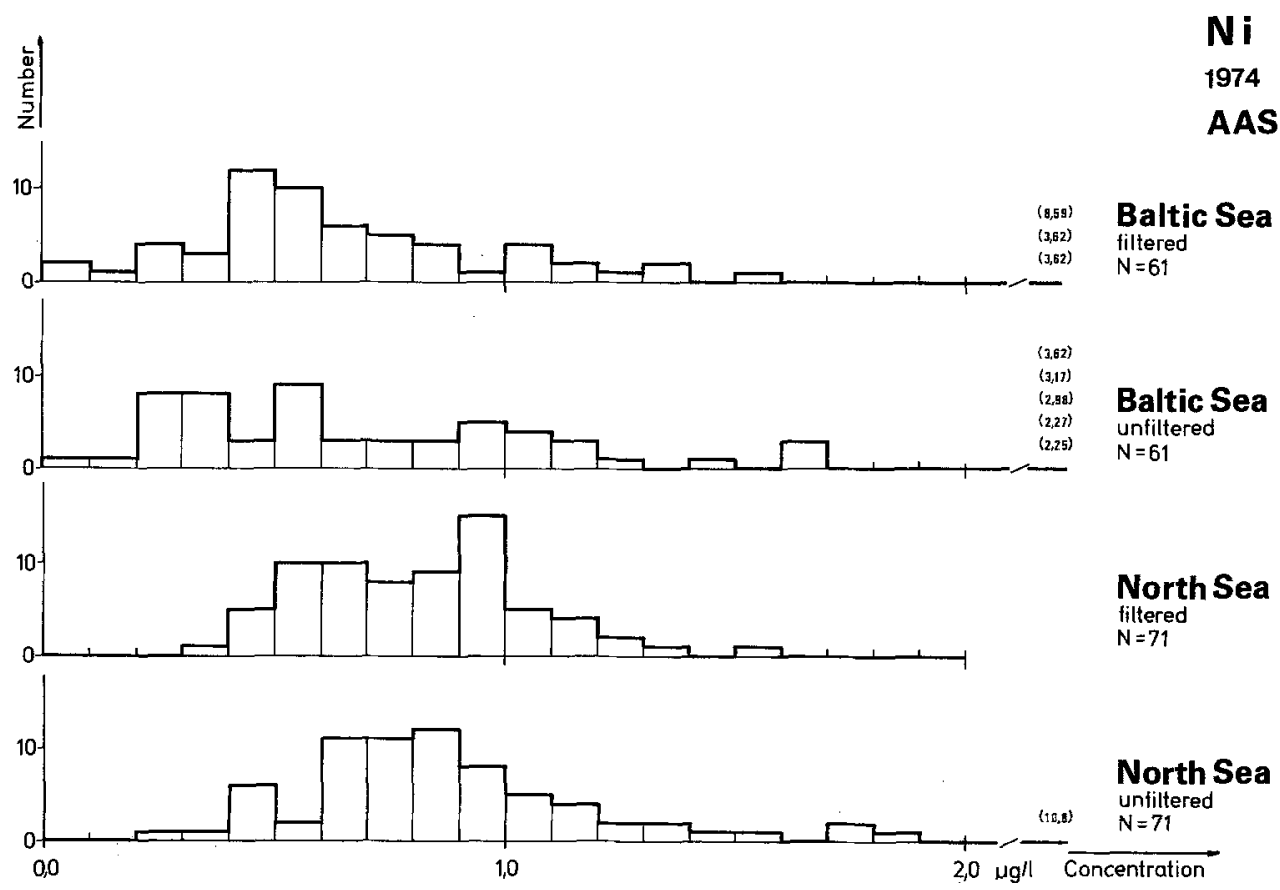

Fig. 8. Histograms for nickel content

southwestern Baltic Sea samples, concentrations are more evenly distributed over the whole range, with some relatively high values far beyond. The latter tendency was displayed for $\mathrm{Mn}$ in the Baltic, but not for Fe. Whereas for German Bight samples the spatial and depth distribution of Ni concentrations does not show any particular structure; increased levels in the Baltic Sea are found at Stations 7, 9, 10 and 11 and in the lowermost sampling bottles only at Stations 15, 16 and 17.

In the present work I have not attempted to compare trace metal data from other authors by entering them into computer calculations. The number of previous investigations in the same areas of the German Bight and the southwestern Baltic Sea that used comparable station networks and similar analytical procedures is very small. In the Baltic Sea, Kremling (1973) and Brügmann (1974) applied the electroanalytical method of anodic stripping voltammetry (ASV) for the determination of dissolved $\mathrm{Zn}, \mathrm{Cd}, \mathrm{Pb}$, and $\mathrm{Cu}$. However, it is now generally accepted that $\mathrm{ASV}$ values for $\mathrm{Cd}$ and $\mathrm{Cu}$ cannot be directly compared with AAS values since the metals are being determined while in different physical and chemical states. For the same reason, our data for $\mathrm{Cd}, \mathrm{Cu}, \mathrm{Zn}$, and $\mathrm{Pb}$ determined by ASV in samples from the same cruise to the German Bight in 1974 have been excluded from computer calculations.

Acknowledgements. The author is particularly grateful to Ms A. Neubauer-Ziebarth and Ms $\mathrm{H}$. Zehle for difficult and tedious analytical work; to Mr. H.-G. Preusse for assistance with sampling and preparation at sea; to officers and crew of RV "Gauss" for support during the cruises; to Mr. P. Freimann, Mr. W. Gerwinski and Ms M. Granegger for developing programs and storage of the data in the desk computer; to Mr. R. Paar for drawing the figures; and to Ms H. Beermann for typing the manuscript. 


\section{LITERATURE CITED}

Anonymous, 1978. Convention on the protection of the marine environment of the Baltic Sea area.Report. 5th meeting of the Interim Commission, 14-17 November 1978, Helsinki, 15.

Bewers, J, M., Topping, G. \& Windom, H. L., 1978. Status and plans regarding ICES intercalibrations for trace metals in seawater. - C.M.-ICES/E 27, 1-10.

Bewers, J. M., Dalziel, J., Yeats, P. A. \& Barron, J. L., 1979. Report of the ICES fourth round intercalibration for trace metals in seawater. - C.M.-ICES/E 37, 1-43.

Brügmann, L., 1974. Die Bestimmung von Zink, Kadmium und Blei in der Ostsee durch inverse Voltammetrie. - Beitr. Meeresk. 34, 9-21.

Jones, P. G. W., 1976. An ICES intercalibration exercise for trace metal standard solutions. - C.M.ICES/E 15, 1-9.

Jones, P. G. W., 1977. A preliminary report on the ICES intercalibration of seawater samples for the analysis of trace metals. - C.M.-ICES/E 16, 1-13.

Kremling, K., 1973. Voltammetrische Messungen über die Verteilung von Zink, Cadmium, Blei und Kupfer in der Ostsee. - Kieler Meeresforsch. 29 (2), 77-84.

Kremling, K. \& Peters, H., 1978. The distribution of Mn, Fe, $\mathrm{Zn}, \mathrm{Cd}$ and $\mathrm{Cu}$ in Baltic seawater; a study on the basis of one anchor station. - Mar. Chem. 6, 155-170.

Schmidt, D, 1976 a. Flammenlose Atomabsorptionsspektrometrie und Invers-Voltammetrie zur Spurenbestimmung von Schwermetallen im Meerwasser der Deutschen Bucht. - Fortschr. Miner. 54, (Beih.1) 147.

Schmidt, D., 1976 b. Determination of cadmium, copper and iron in sea water of the western Baltic. C.M.-ICES/C 9, 1-14.

Schmidt, D., 1976c. Distribution of seven trace metals in sea water of the inner German Bight. C. M.-ICES/C 10,1-14.

Schmidt, D. \& Neubauer, A., 1977. Determination of $\mathrm{Cd}, \mathrm{Cu}, \mathrm{Fe}, \mathrm{Ni}$, $\mathrm{Mn}$ by flameless atomic absorption spectrometry; $\mathrm{Cd}, \mathrm{Cu}, \mathrm{Zn}$, and $\mathrm{Pb}$ by anodic stripping voltammetry, - Report of the Baltic Intercalibration Workshop, Kiel, 7-19 March 1977, Annex, 198-199.

Schmidt, D. \& Zehle, H., 1979. Trace metals in Baltic sea water during BOSEX 77. - C.M.-ICES/C 4, $1-10$.

Weichart, G., 1975a. Untersuchungen über die Fe-Konzentration im Wasser der Deutschen Bucht im Zusammenhang mit dem Einbringen von Abwässern aus der Titandioxid-Produktion. - Dt. hydrogr. Z. 28, 49-61.

Weichart, G., 1975b. Investigations on the Fe concentration in the waters of the German Bight in connection with the dumping of wastes from titanium dioxide production. - C.M.-ICES/C 23, $1-3$. 